\title{
Factors Affecting Farmers' Adoption of Natural Farming Technologies in New Albay, Maragusan, Compostela Valley, Philippines
}

\author{
R.J.G. Lamban, A.K.R. dela Cerna, M.O. Montiflor, R.G. Bacus and S.B. Concepcion \\ University of the Philippines Mindanao \\ Davao \\ The Philippines
}

P.J. Batt and R. Murray-Prior

Curtin University

Perth

Australia

Keywords: cluster marketing, sustainable agriculture, organic fertilizer, conventional farming practices, costs and returns

\begin{abstract}
In the Philippines, the sustainability of natural resources and the profitability of farming has become a major concern for smallholder farmers. To address these concerns, government agencies and the private sector are delivering workshops on natural farming technologies to farmers. Training includes the preparation of different concoctions such as indigenous micro-organisms (IMO), fermented fruit juice (FFJ) and fermented plant juice (FPJ), fish amino acid (FAA), oriental herbal juice (OHN) and calcium phosphate (Caphos). Other natural farm technologies include vermiculture. The products from the training are applied to the farmer's own farms with any surplus products sold to other farmers. In Maragusan, Compostela Valley, Philippines, a group of smallholder farmers have successfully produced organic fertilizers as a result of the training provided to them. Initially, while training was provided to the group to facilitate the marketing of the fresh vegetable crops they produced, the skills learnt were readily transferable. This study discusses the development of the New Albay cluster and factors leading to its decline as a marketing cluster. This study will also explore the costs and returns associated with the application of organic fertilizer to vegetable crops in comparison to conventional farming practices. Results show that the cost of production arising from the use of natural farming technologies is lower than conventional farming.
\end{abstract}

\section{INTRODUCTION}

In the Philippines, the sustainability of natural resources and the profitability of farming is a major concern for smallholder farmers. Because of this, the country is experiencing great difficulty in achieving more production, particularly in the vegetable industry (Montiflor, 2007). Furthermore, environmental concerns have heightened in recent years due to the inappropriate use of modern farming techniques, deforestation and the cultivation of crops in marginal upland areas (Briones, n.d.).

In Maragusan, the United States Department of Agriculture (USDA) funded the Small Farms Marketing Project (SFMP) implemented by the Catholic Relief Services (CRS) with local partner, Kasilak Development Foundation Inc (Kasilak). This project aimed to assist smallholder farmers to improve farm productivity and income through 
combining them into marketing clusters to increase agricultural production and to improve market access. One such group of farmers helped by this project was the New Albay cluster in Maragusan, Compostela Valley, Philippines.

Although the New Albay farmers were largely unsuccessful as a fresh vegetable marketing cluster, the members, on the other hand, were empowered. Through the Department of Agriculture and non-government organizations such as CRS and Kasilak, the cluster received practical knowledge and skills in the Natural Farming Technology System (NFTS). The farmers learned how to make and use organic fertilisers. The products were applied to the farmer's own farms and the surplus product was sold to other farmers.

FAO (1998) are actively encouraging natural farming techniques as one strategy to ensure greater food security. They define natural farming/agriculture as a 'method which uses holistic production management systems which promote and enhance agroecosystem health, including biodiversity, biological cycles and soil biological activity' (p.5). Farmers in the Philippines have adopted and adapted various techniques derived from a number of different philosophies including biodynamic farming, permaculture and natural farming. Natural farming, also known as 'nature farming', is described by Jensen et al. (2006, p.1), as a 'system that promotes a holistic and sustainable approach to agriculture, with the aim of protecting life and the integrity of the natural world'.

This paper discusses the development of the New Albay cluster, the factors leading to its decline as a marketing cluster and its subsequent re-emergence as a natural farming cluster that produces its own inputs and sells its surplus. It also identifies and discusses the reasons for the adoption or partial adoption of natural farming systems by cluster members.

\section{BACKGROUND}

Barangay New Albay is one of the 24 barangays of the municipality of Maragusan, Compostela Valley. New Albay is located 1,900 m above sea level on slopes that range from $0.3 \%$ to $50 \%$ (Barangay Government of New Albay, n.d.). The total population (in 2009) was 3,425, spread across 22 puroks and 709 households. Generally, the residents are Cebuanos, Boholanos, Ilongos and Mansaka/Mandaya.

Of the total land area, 1,000 ha is agricultural land: the remaining 355 ha is forest. The soil type in New Albay is mostly sandy loam and silt loam, which is suitable for crops like banana, corn, vegetables and durian. The main agricultural products cultivated in the barangay include rice (600 ha), corn (300 ha), banana (60 ha), coffee (15 ha), vegetables (5 ha), coconut (5 ha) and fruit trees.

Cluster farming means 'grouping farmers together to consolidate their produce to deliver in bulk, thus saving transportation and transaction costs' (Montiflor et al., 2008, p. 39). The clustering approach developed by CRS (CRS, 2007) is a sequential process involving eight steps that prepares farmers to link with the institutional market through effectively organizing them into small groups or clusters and guiding them in their initial engagement with buyers. The first five steps emphasize the need for farmers to learn new skills, access new information, and adopt innovative methods to be able to identify and respond to market demands and opportunities. Adequate preparation during this critical first phase ensures a higher degree of success when their actual marketing starts to take place in Step 6 (test marketing). After this step, the cluster is asked to reflect and to decide if they want to continue with their agro-enterprise development plans. 


\section{METHODOLOGY}

Personal interviews were conducted among the members of the New Albay cluster using a structured questionnaire. The questionnaire included the farmers' sociodemographic profile, knowledge about natural farming and the reasons/factors for adopting the technology, and a comparison of production costs and returns between conventional farming practices and the natural farming technology system. The number of respondents was pre-determined: they were the original 13 farmers who contributed to the production of natural plant concoctions and organic fertilizers. All of them were to be interviewed, but only 10 of them were available.

Secondary sources of information and the literature was also consulted including information about the New Albay cluster collected during the CRS clustering approach.

\section{DEVELOPMENT OF CLUSTERS IN MARAGUSAN}

The Maragusan Vegetable Farmers' Cluster was formed in 2006 from six barangays in the municipality. From its foundations, the cluster had grown to 174 farmers by 2007 who collectively sold their vegetables through the cluster (Montiflor et al., 2008).

\section{Factors Leading to the Decline of the Marketing Clusters}

While the cluster was successful initially, it soon began to disintegrate as some barangays fell away. The factors that led to the decline included: financial sustainability in the absence of financial support from funding agencies; the legal status of the cluster group; the need for additional volume and product assortment; the lack of marketing options; inaccessible farm-to-market roads; and gold mining (Montiflor et al., 2008).

The Maragusan vegetable farmers predominantly plant chayote. During their trial deliveries to public markets in Cagayan de Oro and Davao and to a supermarket in Davao, the returns were encouraging. However, the markets were unable to absorb all the chayote produced and prices declined.

Since the prices the cluster members received were not substantially higher than those realised from the traditional markets (wet markets and trading posts), the cluster members continued to sell to the traditional market. The cluster also stopped deliveries to Cagayan de Oro because they could not compete with cheaper product from nearby vegetable producing areas such as Bukidnon. On one occasion, as the truck carrying the chayote broke down, they missed the ship leaving for Manila.

Institutional support organizations were crucial to the creation, development and growth of the clusters. In Maragusan, USDA funded CRS to implement the project with local partner Kasilak, who provided additional funding and assistance. The supporting institutions provided the majority of the funding, including the salaries of the Marketing Officer and Development Officer, travel, supplies and a communication allowance. The main reason why the Maragusan Vegetable Farmers' cluster worked, despite the small volume of sales, was because staff and funding were present. However, when CRS funding ended after the first quarter of 2008, the support could not be sustained and the clusters declined.

While the farmers and their cluster leaders were working together, their group was not registered as a legal body with the Securities and Exchange Commission (SEC), the Department of Trade and Industry (DTI), the Cooperative Development Authority (CDA), or the Department of Labor and Employment (DOLE). The group were unable to get any support from other agencies or funding institutions because they did not have any legal structure. This meant that the group would exist only for as long as the project 
existed. Technically, they could not trade as a group or issue receipts.

Another factor that led to the decline of the cluster were emerging job opportunities in the mining industry. Many farmers stopped growing vegetables and opted to work on the mine site as the daily income that they received was significantly higher than what they could earn from harvesting their vegetables. This resulted in a decline in the number of members and not unexpectedly, to a decline in the number and quantity of vegetable products consolidated by the cluster.

A key constraint for the clusters was the poor state of the main road leading from Maragusan to nearby cities and municipalities. During wet weather, the road often became impassable. Almost $90 \%$ of the roads are made of gravel, not concrete, and the farm-to-market roads are worse. Although tomatoes are a suitable crop for farmers to grow, especially at high elevation, the roads are muddy and slippery, and so it became too difficult to transport the fruit and maintain the consistency of supply required by the institutional buyers.

However, despite the initial failure of the cluster, the members had all gained valuable skills and knowledge. The Department of Agriculture and non-government organizations such as CRS and Kasilak had provided farmers with practical knowledge and skills in the Natural Farming Technology System (NFTS). These trainings included the production of different concoctions such as indigenous microorganisms (IMO), fermented fruit juice (FFJ), fermented plant juice (FPJ), Fish Amino Acid (FAA), Oriental Herbal Juice (OHN) and calcium phosphate (Caphos). Other natural farm technologies included vermiculture. These products were applied to the farmer's own land and surplus product was sold to other farmers.

\section{THE NEW ALBAY CLUSTER}

The New Albay cluster was one of the original six barangays involved in the Maragusan vegetable marketing cluster. Members of the cluster were predominantly female with ages ranging from 37-66 years. Only one of the members had any college education, with most members only having some elementary or high school education. Five of the eight members interviewed had a monthly income of PhP 1,000 - 3,000. With the poverty threshold estimated to be PhP 1,221 per month in Compostela Valley (NSCB, 2007), this suggested that the majority of group members were living at or below the poverty line

Most of the respondents spoke the same language or local dialect, which made it easier for them to communicate. The support extended by NGOs and the LGU to the cluster also contributed to the strengthening of the group. Moreover, effective leadership also made a great contribution to maintaining the cluster.

\section{ADOPTION OF NFTS BY NEW ALBAY CLUSTER}

Among the 13 farmers in the New Albay cluster, three of them used the natural farming method, while the remainder used both natural farming and conventional farming methods.

Those who responded to the NFTS survey, ten became aware of the Natural Farming Technology System through various seminars and workshops they had attended. Information from the LGU staff, NGO staff, organizations and neighbours were the most popular sources of information. Six respondents had listened to radio and television programs, while three respondents indicated that newspapers and pamphlets were their other principal sources of information. 
All respondents identified the cost effectiveness of natural farming as one of the factors that most influenced their decision to adopt natural farming technologies. All of the New Albay respondents said that natural farming technologies were cheaper and more accessible (Table 1) as the need to invest a lot of capital had been substantially reduced. Instead of buying expensive inorganic fertilizers, pesticides, herbicides and other output enhancing chemicals, the use of natural farming technologies had lowered their costs of production thereby improving their net income. The costs of production were reported to have declined by $2.3 \%$ to $46.5 \%$ after the partial and full adoption of NFTS compared to the costs incurred with conventional farming. According to Kumar (n.d.), many of the smallholder farmers who use conventional farming technology are in debt because of the high cost of fertilizers and pesticides. As market prices are often low, farmers were unable to recover their costs.

An additional benefit of NFTS was that it reduced health risks. All respondents considered natural farming technologies' to make a positive contribution to health, safety and the environment as additional factors encouraging adoption. One of the respondents emphasized that her health was better now that she was eating vegetables that had been produced under a natural farming system rather than under a traditional inorganic system. This result confirms the findings of Canavari, Lombardi and Cantore (2007) who suggested that the probability of adopting organic farming practices was affected by ideological motivations such as health and environmental protection. De Cock (2005) found that organic farmers in Belgium placed more importance on reducing the impact of their farming practices on the environment.

Six respondents considered the easy preparation of inputs as a factor that encouraged them to adopt NFTS. Farmers can buy organic fertilizers and pesticides in their group or in stores that sell agricultural products in the area.

Other factors like the popularity of NFTS and getting a higher market price for organically produced crops have not yet been considered by the respondents. Most of the respondents indicated that they had not received a higher price because their vegetables had been produced using NFTS methods as the traditional wet market did not differentiate between how products were produced. As a result, the vegetables produced from natural farming systems received the same price as those produced using conventional farming systems. This is quite different in many of the world's more mature markets, where products produced under natural farming systems did receive a higher price (Ballo, 2008).

\section{CONCLUSIONS}

Cluster farming groups were originally formed to assist farmers in selling their vegetable products. All cluster farming groups went through the CRS eight-step clustering approach of cluster formation. The first five steps help farmers to gain new skills, access new information, and adopt innovative methods that will support them to identify and respond to market demands and opportunities, given their capabilities.

However, cluster farming groups have struggled as marketing clusters in Maragusan, due to a range of factors including the choice of crops, competition for labour, poor roads and the lack of any price premiums. During the formation of the clusters, New Albay cluster members attended trainings and seminars about vegetable farming and ways to improve it. One of these trainings was on making organic fertilisers. It made it possible for farmers in the New Albay cluster to organise themselves to produce and to use organic inputs, either in natural farming systems or in combination with non-organic inputs. 
Factors such as cost effectiveness, the ease of preparation, reduced health risks and a positive contribution to the environment were identified as the factors that most influenced the farmers to partially or fully adopt natural farming technologies. On the other hand, the popularity of natural farming technologies and high market price were never considered by respondents' in their decision to adopt natural farming technologies.

Even though the cluster did not succeed as a marketing group, the members were empowered to continue as a group, but this time with a different objective. The trainings and interventions provided by both government and non government agencies, contributed to building up the capacity of the farmers in New Albay. The assistance, material and capacity building provided by these agencies helped the farmers develop new skills and competencies that they can use not only with their enterprise but more so in their everyday lives.

\section{Literature Cited}

Aguhob, R.C. 2009. Indigenous Micro-Organism products bring cash to barangay residents in Oroquieta City. Retrieved on November 4, 2009 from http://www.pia.gov.ph/?m=12\&fi=p090529.htm\&no=52.

Barangay Government of New Albay. 2009. New Albay, Maragusan, Compostela Valley, Philippines.

Briones, N.D. n.d. Environmental Sustainability Issues in the Philippine Agriculture. Retrieved on November 24, 2009 from http://www.searca.org/web/e_library/asian\%20journal\%20of\%20agriculture\%20and\% 20development $\% 20 \% 28$ vol\%202\%20nos\%201\%20and\%202\%29/briones.pdf

Canavari, M. Lombardi, P. and Cantore, N. 2007. Factors explaining farmers' and intentions about agricultural methods of production. Organic vs. conventional comparison. Retrieved on October 20, 2009 from http://orgprints.org/12577/1/12577.pdf.

Concepcion, S.B. 2005. Household Purchase on Consumption Habits for Vegetable in Three Major Cities in Mindanao. Davao City.

CRS-Philippines. 2007. The Clustering Approach to Agroenterprise Development for the Small Farmers: The CRS-Philippines Experience. A Guidebook for the Facilitators. Davao City, Philippines.

De Cock, L. 2005. Determinants of organic farming conversion. Paper prepared for the poster presentation of the XIth International Congress of European Association of Agricultural Economists, August 24-27, 2009, Copenhagen, Denmark.

Dela Cruz, R. T. 2004. Natural farming system: The living agriculture. Article published in the Department of Agriculture Research - Department of Agriculture, Philippines. December 1-31, 2004. Vol.5 No.12 Issue. Retrieved on May 14, 2010 from http://www.bar.gov.ph/barchronicle/2004/dec04_1-31_naturalfarm.asp.

Food and Agriculture Organization of the United Nations. 1998. Evaluating the Potential Contribution of Organic Agriculture to Sustainability Goals. FAO's technical contribution to IFOAM's Scientific Conference, November 16-19, 1998, Mar del Plata, Argentina.

Hattam, C.E. and Holloway, G.J. n.d. Adoption of Certified Organic Production: Evidence From Mexico. Retrieved on November 9, 2009 from http://orgprints.org/4367/4/4367-Hattam_Holloway_4p_revised-ed.pdf 
Jensen, H., Guilaran, L., Jaranilla, R. and Garingalao, G. 2006. Nature Farming Manual. Retrieved on January 27, 2010 from http://www.scribd.com/doc/15766334/NaturalFarming-With-Organic-and-Biological-Technology-With-HOC

Kasse, M., Zikhali, P., Manjur, K. and Edwards, S. 2009. Adoption of Organic Farming Techniques Evidence from a Semi-Arid Region of Ethiopia. Environment for Development. Retrieved on November 9, 2009 from http://www.rff.org/RFF/Documents/EfD-DP-09-01.pdf

Kumar, T.V., Raidu, D.V., Killi, J., Pillai, M., Shah, P., Kalavadonda, V. and Lakhey, S. (n.d.). Ecologically Sound, Economically Viable - Community Managed Sustainable Agriculture in Andhra Pradesh, India. Retrieved on January 27, 2010 from http://www.scribd.com/doc/21632080/Ecologically-Sound-Economically-ViableCommunity-Managed-Sustainable-Agriculture-in-Andhra-Pradesh-India.

Mendoza, T.C. 2008. Nature farming in the Philippines. University of the Philippines Los Banos. Philippines. Retrieved on October 20, 2009 from http://www.infrc.or.jp/english/KNF_Data_Base_Web/PDF\%20KNF\%20Conf\%20Dat a/C1-4-011.pdf

Montiflor, M.O. 2007. Cluster Farming as a Vegetable Marketing Strategy: A Case of Smallholder Farmers in Southern and Northern Mindanao.. Acta Hort. 794:229-238.

Montiflor, M.O., Batt, P.J. and Murray-Prior, R. 2008. Cluster farming definition: Cluster Farms in Mindanao: Are Smallholder Farmers Expectations Being Fulfilled?. Banwa Management Vol. 5, No. 2. University of the Philippines Mindanao, Davao City, Philippines.

National Statistics Coordination Board. 2007. Annual Per Capita Poverty Thresholds by Province, 2006 - 2007. Retrieved on November 19, 2009 from http://www.nscb.gov.ph/poverty/2006-2007/pov_th_07.asp

Table 1: Factors affecting farmers' adoption of natural farming technologies

\begin{tabular}{lll}
\hline Factors & \# mentions & $\begin{array}{l}\text { Ranking } \\
\text { (Mean) }\end{array}$ \\
\hline Cheap and cost-effective & 10 & 1.1 \\
Natural Farming technologies reduce health risks & 10 & 2.6 \\
Natural Farming technologies are environment-friendly & 10 & 3.0 \\
Inputs are easy to prepare & 6 & 3.3 \\
Natural Farming technologies are popular or trendy & 0 & \\
Market Price of the produce is higher. & 0 & \\
\hline
\end{tabular}

